one who is interested in the history of medicine will wish this new journal well and will hope that it will, before long, be able to stand by itself. Meanwhile, its fusion with the Medical Bookman is complete. The reader of the combined journal will, in fact, scarcely know which of the contributions belong to either partner in this interesting marriage. Eleven of the fifteen items in the list of contents of the November issue (Vol. 1, No. 11) are reviews of books, the other five being original articles; interesting as the kind of book review here printed certainly is, some readers may prefer to see by a glance at the list of contents which are the original articles and which the book reviews. Three of the articles in this issue are the first articles of a series, namely, "Bypaths in Medical Bibliography", by W. J. Bishop, librarian of the Wellcome Historical Medical Museum, "British Historians of Medicine", by F. N. L. Poynter and W. J. Bishop, and "Rise, Fall and Revivals of Hospitals", by Prof. J. A. Nixon. The other article is by the editor of the Medical Historian, W. R. Bett, on "Some Thyroid Pioneers". A notice on the front cover of the journal briefly reports the inaugural meeting of the new Medical Sub-section of the Library Association, which fulfils a suggestion made by Sir William Osler in 1909. The honorary secretary of this sub-section is W. J. Bishop, The Wellcome Historical Medical Museum, 26 Portman Square, London, W.1. An exchange system for duplicate or unwanted books and journals, lists of periodicals and rare books, inter-library loans and other services are contemplated. This is a development which everyone engaged in biological work will heartily welcome.

\section{Sun-Bathing by Birds}

Records compiled by John Gibb (Brit. Birds, 50, No. 6 ; June 1947) show that sun-bathing is a regular habit among passerine and predatory birds. The attitudes adopted show an obvious similarity between different species, whether the bird is facing into or away from the sun. This is typically the fluffing out of the body feathers, opening of the wings and fanning the tail. The odd postures at times may usually be attributed to the bird inclining its body towards the oblique rays of the sun. Juvenile birds are particularly prone to sun-bathing. The suggested part that sun-bathing may play in the process of moult is less clearly indicated, although the dates of records show a tendency to concentrate at times of moult.

\section{Botanical Expedition to Nigeria}

A SMall botanical expedition, under the leadership of Dr. P. W. Richards (Botany School, Cambridge), left England on November 15 for Nigeria. The party includes Dr. G. C. Evans (Botany School, Cambridge) and Dr. E. W. Jones and Mr. J. P. M. Brenan (Imperial Forestry Institute, Oxford), and will continue work in the field until the beginning of April 1948. The chief object of the expedition is to investigate the process of natural regeneration in the evergreen tropical forest, with special reference to Aubréville's 'Mosaic Theory'. It is expected that the greater part of the work will be carried out in the forest reserves of Benin Province; but if circumstances permit, some members of the party will visit the Cameroons and make an ecological study of the little-known montane forests. The expedition has the financial support of the Royal Society and of the Colonial Research Fund.

\section{Ministry of Agriculture and Fisheries: Appoint- ments}

THE following appointments have been announced by the Ministry of Agriculture and Fisheries : Prof. J.A. Scott Watson, chief education and advisory officer to the Ministry, formerly Sibthorpian professor of rural economy, University of Oxford, to be chief scientific and agricultural adviser to the Ministry and directorgeneral of the National Agricultural Advisory Service, in succession to Sir William Gavin, who retires on December 31 ; Mr. Robert Rae, an under-secretary in the Ministry, formerly professor of agriculture in the University of Reading, to be director of the National Agricultural Advisory Service; Mr. F. Grant, principal assistant secretary in the Ministry, to be an under-secretary; Mr. H. G. Lambert, a principal in the Ministry, to take charge of a new branch to organise the special campaign for grassland development recently announced by the Minister as part of the new agricultural expansion programme, the technical officer in charge of which is Mr. W. H. Hay.

\section{Announcements}

WE regret to announce that Prof. G. H. Hardy, emeritus professor of pure mathematics in the University of Cambridge, died on December 1; on that day he should have received the Copley Medal of the Royal Society, the award of which to him was announced a short time ago.

THE Lord President of the Council has appointed Sir Frank Engledow, Draper's professor of agriculture in the University of Cambridge, to be chairman of the Food Investigation Board, Department of Scientific and Industrial Research, in succession to the late Sir Joseph Barcroft.

Mr. E. A. Evans, chief chemist to the Wakefield Group of companies since 1915, has been nominated president designate of the Institute of Petroleum for the session 1948-49. Mr. Evans has been chairman of the Motor Industry Research Association since its inception in March 1946; and was chairman of its predecessor-the Automobile Research Committeoduring 1944 and 1945. In 1942-43 he was awarded the Crompton Medal of the Institution of Automobile Engineers for his paper on "Extreme-Pressure Lubrication".

THE British Social Hygiene Council is arranging a conference on "Biology in Education", to be held at University College, London, on December 30. Speakers include Prof. J. Z. Young, Mrs. F. M. Holt and Mr. W. L. Sumner. Further information can be obtained from the Secretary, British Social Hygiene Council, Tavistock House North, Tavistock Square, London, W.C.l.

AN Italian Association for the Progress of Zootechny has been established at Milan, under the chairmanship of Prof. T. Bonadonna, of the University of Milan and director of the Lazzaro Spallanzani Experimental Institute for Artificial Insemination.

THE report of the Archæological Survey of the Union of South Africa for the period April 1940March 1946 has appeared (Pretoria : Gov. Printer). Both in quaternary geological studies and in work on prehistoric art, there has been much activity. Dr. van Riet Lowe has had Prof. H. Breuil with him for much of the period under review, and a number of papers and other publications have been issued. 